\title{
Isolation and some properties of an iridovirus-like agent from white sturgeon Acipenser transmontanus
}

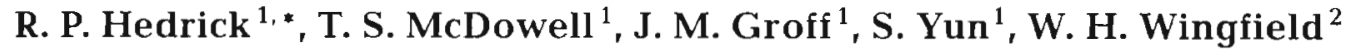 \\ ${ }^{1}$ Department of Medicine, University of California, Davis, California 95616, USA \\ ${ }^{2}$ California Department of Fish and Game, Fish Disease Laboratory, Rancho Cordova, California 95670, USA
}

\begin{abstract}
An iridovirus-like agent (WSIV) associated with fatal infections of the integument of juvenile white sturgeon Acipenser transmontanus was isolated from fish that exhibited gross and microscopic signs of the disease. The virus induced cell enlargement and slowly progressive degeneration of a recently established cell line from white sturgeon spleen (WSS-2). Virus replication occurred at 10, 15 and $20^{\circ} \mathrm{C}$ but not at 5 or $25^{\circ} \mathrm{C}$. The most rapid growth occurred initially at $20^{\circ} \mathrm{C}$ but the greatest concentrations $\left(10^{6} \mathrm{TCID}_{50} \mathrm{ml}^{-1}\right)$ of cell-free virus were detected at 10 and $15^{\circ} \mathrm{C}$. Numerous virions were observed in the cytoplasm of infected WSS-2 cells and ca $70 \%$ of the infectious virus remains cellassociated. Virions possessed an external capsid with an envelope of 260 to $280 \mathrm{~nm}$ in diameter that surrounded an inner capsid with a dense nucleoid. Residual viral infectivity (ca $1 \%$ ) was found following incubation of the virus at a temperature of $56^{\circ} \mathrm{C}$ for $30 \mathrm{~min}$. The WSIV genome is presumably DNA since $50 \mu \mathrm{g} \mathrm{ml}^{-1}$ 5-bromo-2'-deoxyuridine completely inhibited viral replication in the WSS-2 line. Virulence for juvenile sturgeon of virus grown in WSS-2 cells was demonstrated by induction of fatal infections $\left(80 \%\right.$ cumulative mortality) following bath exposures to the virus at concentrations of ca $10^{3}$ $\mathrm{TCID}_{50} \mathrm{~g}^{-1}$ fish for $30 \mathrm{~min}$. There were no mortalities among lake sturgeon Acipenser fulvescens, striped bass Morone saxatilis or channel catfish Ictalurus punctatus following bath exposures to the same concentrations of virus $\left(\mathrm{TCID}_{50} \mathrm{~g}^{-1}\right.$ ) but the agent was recovered from lake sturgeon examined at 1 and 2 wk post-exposure. Microscopic signs of experimentally-induced infections included: presence of large amphophilic to deeply basophilic cells; epithelial hyperplasia and degeneration; necrosis in the integument and gill epithelium of white surgeon. Lake sturgeon examined at 1 and 2 wk postinfection demonstrated a similar response, although the cellular hypertrophy was not prominent compared to that observed in white sturgeon.
\end{abstract}

\section{INTRODUCTION}

The rearing of juvenile white sturgeon Acipenser transmontanus at several farms in Northern and Central California (USA) has been plagued by annual losses due to viral infections. Three viruses have been found associated with infections of the epithelium of either the intestinal tract, integument or gills of juvenile white sturgeon. An adenovirus-like agent in the mucosal cells of the intestinal linining (Hedrick et al. 1985), an iridovirus-like agent in the epidermis and respiratory epithelium (Hedrick et al. 1990), and most recently a herpesvirus in the epidermis (Hedrick et al. 1991a) have been observed in diseased white sturgeon. The white sturgeon iridovirus-like agent (WSIV)

\footnotetext{
- Addressee for correspondence
}

is the most serious of the 3 viral agents because it is more frequently encountered and is associated with the greatest losses (up to $95 \%$ mortality).

Epithelial cells of the skin and gills infected with WSIV become enlarged, and virions with a mean diameter of $262 \mathrm{~mm}$ can be found within these cells. Presumptive diagnosis of WSIV infection currently relies on observation of these pathognomonic cellular changes as detected in hematoxylin and eosin stained tissue sections.

Confirmatory diagnoses require demonstration of the presence of characteristic virus particles within infected cells by electron microscopy. Further characterization of WSIV has been impeded by the inability to isolate the agent in cell cultures. Initial attempts to isolate WSIV were unsuccessful in part due to the lack of suitable cell lines. We have recently developed 3 cell 
lines from white sturgeon, and the line from spleen (WSS-2) has been found to support replication of WSIV (Hedrick et al. 1991b). The purpose of the following report is to provide information on isolation, cytopathology and virus replication at selected temperatures in the WSS-2 line. In addition, the nucleic acid type and sensitivity of the virus to chloroform and temperature were examined. Lastly, the virulence of WSIV was evaluated following waterborne exposures of white sturgeon, lake sturgeon Acipenser fulvescens, channel catfish Ictalurus punctatus and striped bass Morone saxatilis.

\section{MATERIALS AND METHODS}

Fish. Juvenile white sturgeon (1 to $20 \mathrm{~g}$ ) from populations experiencing an increased mortality were collected from 3 farms in California (USA) with a previous history of microscopic signs of WSIV infections. The fish were examined for external and internal pathogens (e.g. parasites, bacteria, viruses) using standard methods (Amos 1985). Small fish used for virus isolation were homogenized whole as 5-fish pools. In larger fish, a portion of the gill lamellae and a piece of opercular skin were removed for homogenization and subsequent virus isolation.

Juvenile white sturgeon $(6.4 \mathrm{~g})$ used for experimental exposures to the virus were obtained as fry directly from a farm prior to movement from the quarantine area to the production facility. The white sturgeon were reared in $15^{\circ} \mathrm{C}$ well water at the University of California, Davis, Fish Disease Laboratory, prior to use in experimental studies. Initial histological examinations of these fish showed no evidence of viral infection. Healthy lake sturgeon ( $4.5 \mathrm{~g})$, channel catfish (1.6 g) and striped bass ( $6.6 \mathrm{~g})$ were obtained from Wisconsin Department of Natural Resources and 2 local fish farms, respectively. The fish were maintained in $130 \mathrm{l}$ aquaria receiving $15^{\circ} \mathrm{C}$ well water. All fish were fed a commercial moist trout diet.

Cells and virus isolation. Two standard cell lines for isolation of salmonid viruses and 3 lines from white sturgeon were used in attempts to isolate or propagate the virus. These included the chinook salmon embryo line, CHSE-214 (Lannan et al. 1984), the cyprinid epithelial line, EPC (Fijan et al. 1983), the white sturgeon heart (WSH-1), spleen (WSS-2), and skin (WSSK1) lines (Hedrick et al, 1.991b and unpubl. data). All cell lines were propagated at $20^{\circ} \mathrm{C}$ in minimal essential medium (MEM) with Earle's salts supplemented with $10 \%$ fetal bovine serum (FBS), $50 \mathrm{IU} \mathrm{ml}^{-1}$ penicillin, $50 \mu \mathrm{g} \mathrm{ml}^{-1}$ streptomycin and $2 \mathrm{mM} \mathrm{L-glutamine.}$

Replicate wells of a 12-well tissue culture dish (ca $10^{5}$ cells) were inoculated with $0.2 \mathrm{ml}$ of a 1:50 dilution $(w / v)$ of the initial tissue extract. After an adsorption period of $1 \mathrm{~h}$ at $23^{\circ} \mathrm{C}, 1.5 \mathrm{ml}$ of MEM with $2 \% \mathrm{FBS}$ (MEM-2) was added to each well of the plate which was incubated at $20^{\circ} \mathrm{C}$ and observed daily for evidence of cytopathic effects (CPE). After CPE were observed, a $0.2 \mathrm{ml}$ aliquot of culture fluid with cells scraped from the monolayer was used to inoculate a 25 $\mathrm{cm}^{2}$ flask with a $50 \%$ monolayer of WSS-2 or WSSK-1 cells. Virus in the supernatant and associated with the cells remaining after $28 \mathrm{~d}$ incubation at $20^{\circ} \mathrm{C}$ was then evaluated. Cells were separated by centrifugation at $2500 \times g$ for $5 \mathrm{~min}$ and then resuspended in $5 \mathrm{ml} \mathrm{MEM}$ and sonicated for $10 \mathrm{~s}$. The concentrations of virus in the sonicated suspension and the original supernatant were then determined hy TC.ID 50 analysis on WSS 2 cells incubated at $20^{\circ} \mathrm{C}$ for $28 \mathrm{~d}$. Virus infectivity was then estimated (Reed \& Meunch 1938) and expressed as the $\mathrm{TCID}_{50} \mathrm{ml}^{-1}$. Stock virus suspensions, obtained after 2 passages in WSS-2 cells, were stored at $-70^{\circ} \mathrm{C}$.

Light microscopy. Five moribund fish from the same population used for virus isolations were examined by standard histological methods to confirm the presence of pathognomonic signs of WSIV infection. An incision in the abdomen was made to expose the visceral contents, and the entire fish was placed into Bouin's fixative (Humason 1979). After 24 to $48 \mathrm{~h}$ of fixation, samples were transfered to $70 \%$ ethanol and processed for standard paraffin embedding and sectioning. Tissue sections $(5 \mu \mathrm{m})$ were stained with hematoxylin and eosin

Infected WSS- 2 cells were fixed after $10 \mathrm{~d}$ incubation at $15^{\circ} \mathrm{C}$ in $10 \%$ neutral buffered formalin and stained with Leishman-Giemsa reagent (Yasutake \& Wales 1983).

Electron microscopy. WSS-2 cells infected with WSIV at an MOI of 0.01 were fixed after $21 \mathrm{~d}$ incubation at $20^{\circ} \mathrm{C}$ while still attached to the flask with $2.5 \%$ glutaraldehyde in $0.06 \mathrm{M}$ cacodylate buffer ( $\mathrm{pH} 7.4$ ) for 2 h at $4{ }^{\circ} \mathrm{C}$. Cells were rinsed twice in buffer, removed from the flask by scraping and then sedimented by centrifugation at $1500 \times \mathrm{g}$ for $10 \mathrm{~min}$. The pellet was then post-fixed in $1 \%$ aqueous $\mathrm{OsO}_{4}$, dehydrated through a graded ethanol series, infiltrated and embedded in epoxy resin. Thin sections (10 to $20 \mathrm{~nm}$ ) were stained with $4 \%$ uranyl acetate and lead citrate prior to examination with a Phillips EM 400 electron microscope at $80 \mathrm{kV}$.

Growth temperatures. Growth of WSIV was examined at $5,10,15,20$ and $25^{\circ} \mathrm{C}$ in WSS- 2 cells. Five replicate $25 \mathrm{~cm}^{2}$ flasks of WSS-2 cells were grown to ca $80 \%$ monolayers at $20^{\circ} \mathrm{C}$. The cells in each flask were inoculated with $100 \mathrm{TCID}_{50}$ of WSIV. After adsorption. of the virus for $30 \mathrm{~min}$ at $20^{\circ} \mathrm{C}, 5 \mathrm{ml}$ of MEM-2 was added to each flask. One flask was then placed at each of the selected temperatures. At selected intervals 
between 1 and $64 \mathrm{~d}$ after inoculation, a $0.1 \mathrm{ml}$ aliquot removed from each flask was titrated on WSS- 2 cells incubated at $20^{\circ} \mathrm{C}$ for $28 \mathrm{~d}$

Determination of nucleic acid type, chloroform sensitivity and temperature stability. Determination of the nucleic acid type of WSIV using 5-bromo-2'-deoxyuridine $\left(50 \mu \mathrm{g} \mathrm{ml}^{-1}\right)$, and sensitivity of the virus to chloroform and temperature $\left(56^{\circ} \mathrm{C}\right.$ for $\left.30 \mathrm{~min}\right)$ were determined by the methods described by Rovozzo \& Burke (1973). Channel catfish virus (CCV) strain CA-80 and infectious pancreatic necrosis virus (IPNV) strain VR 299 were used as control DNA/enveloped and RNA/ nonenveloped viruses. These 2 control viruses were grown and titered as described previously (Hedrick \& McDowell 1987, Hedrick et al. 1991c). Two aliquots were removed from each control and treated flask or tube and were titered for the amount of infectious virus by TCID $_{50}$ analyses on WSS- 2 cells incubated for $28 \mathrm{~d}$ at $15^{\circ} \mathrm{C}$.

Transmission trial. Two experimental groups of 20 and 19 fish respectively, for white and lake sturgeon, and 2 experimental groups of 25 fish each of channel catfish and striped bass were placed into $130 \mathrm{l}$ aquaria containing $0.75 \mathrm{l}$ of $15^{\circ} \mathrm{C}$ well water with $10^{29} \mathrm{TCID}_{50}$ of WSIV $\mathrm{g}^{-1}$ fish. After $30 \mathrm{~min}$, the flow of well water was resumed to the aquaria. Two control groups of all 4 species of fish, containing equal numbers of fish as experimental groups, were treated in the same manner but exposed using $250 \mathrm{ml}$ of MEM. Dead fish were examined for presence of the virus, and virus concentrations determined for several fresh white sturgeon mortalities. In addition, fish were removed from one of the parallel virus-exposed and control groups at selected intervals. This sampling consisted of: 4 fish from the white and lake sturgeon groups; 5 fish from the channel catfish and striped bass groups at 1,2, 4 and 6 wk; and the fish remaining at 9 wk after infection. Because of mortalities among white sturgeon, only 2 live fish were removed at $6 \mathrm{wk}$ postinfection. Two gill arches and a portion of the operculum were removed from each fish and processed according to standard procedures for virus isolation employing WSS- 2 cells at $20^{\circ} \mathrm{C}$. The cells were observed for viral cytopathic effects over a period of up to $42 \mathrm{~d}$. Four fish from the virus-exposed and control white and lake sturgeon groups used for virus isolations were also examined by standard histological procedures (Humason 1979) for evidence of WSIV infection.

\section{RESULTS}

\section{Virus isolation}

Enlarged cells in the WSS-2 line were first noticed at $14 \mathrm{~d}$ post-inoculation. The cells progressively became more rounded, began to detach and eventually lysed by $21 \mathrm{~d}$ after inoculation with extracts from infected white sturgeon. There was no evidence for CPE in the WSH-1, CHSE-214 or EPC cells. Although not used in initial isolations, subcultures of the virus onto WSSK-1 cells induced CPE after 28 d at $20^{\circ} \mathrm{C}$ but the more complete cell lysis observed in WSS-2 cells did not occur. A comparison of cell-free and cell-associated virus content showed that substantial amounts of virus (ca $70 \%$ remained in these cells. Using these same isolation procedures, the virus was identified at 3 rearing facilities with infected white sturgeon in California.

\section{Light microscopy}

Stained tissue sections of the integument and gills of all 5 fish from one of the naturally-infected populations examined showed the presence of the large hypertrophied, amphophilic to strongly basophilic staining cells as previously reported for WSIV infections (Hedrick et al. 1990). Similar cellular changes were observed in infected WSS-2 cells. Cell monolayers contained large basophilic cells with cytoplasmic inclusion bodies (Fig, 1A). Beginning at $10 \mathrm{~d}$ after virus infection and up to the time of detachment of infected cells at $21 \mathrm{~d}$, there was a progressive increase in the numbers of fused cells with pleiomorphic nuclei and deeply stained cytoplasmic inclusion bodies.

\section{Electron microscopy}

At $21 \mathrm{~d}$ following infection with WSIV, the WSS-2 cells had abundant vacuoles, degenerative endoplasmic reticula and a fine granularity to the cytoplasm. Distributed throughout the cytoplasm were numerous mature and developing virions (Fig. 1B). Mature virions were characterized by an internal shell of $183 \mathrm{~nm}$ that contained an electron-dense bar of $148 \mathrm{~nm}$ in length (Fig. 1C). The inner shell was surrounded by a second outer shell or capsid measuring $273 \mathrm{~nm}$ in diameter (side to side). The thickness of the outer and inner shells were 10 to $12 \mathrm{~nm}$ which suggests they possess more than a single unit membrane (6 to $7 \mathrm{~nm}$ ).

\section{Growth temperatures}

Virus replication occurred at 10,15 , and $20^{\circ} \mathrm{C}$ but not at 5 or $25^{\circ} \mathrm{C}$. Initial virus growth was most rapid at $20^{\circ} \mathrm{C}$ but the greatest production of virus was detected at 10 and $15^{\circ} \mathrm{C}$ (Fig. 2). The highest concentration of virus detected was $10^{5.8} \mathrm{TCID}_{50} \mathrm{ml}^{-1}$ after $50 \mathrm{~d}$ at $15^{\circ} \mathrm{C}$. 

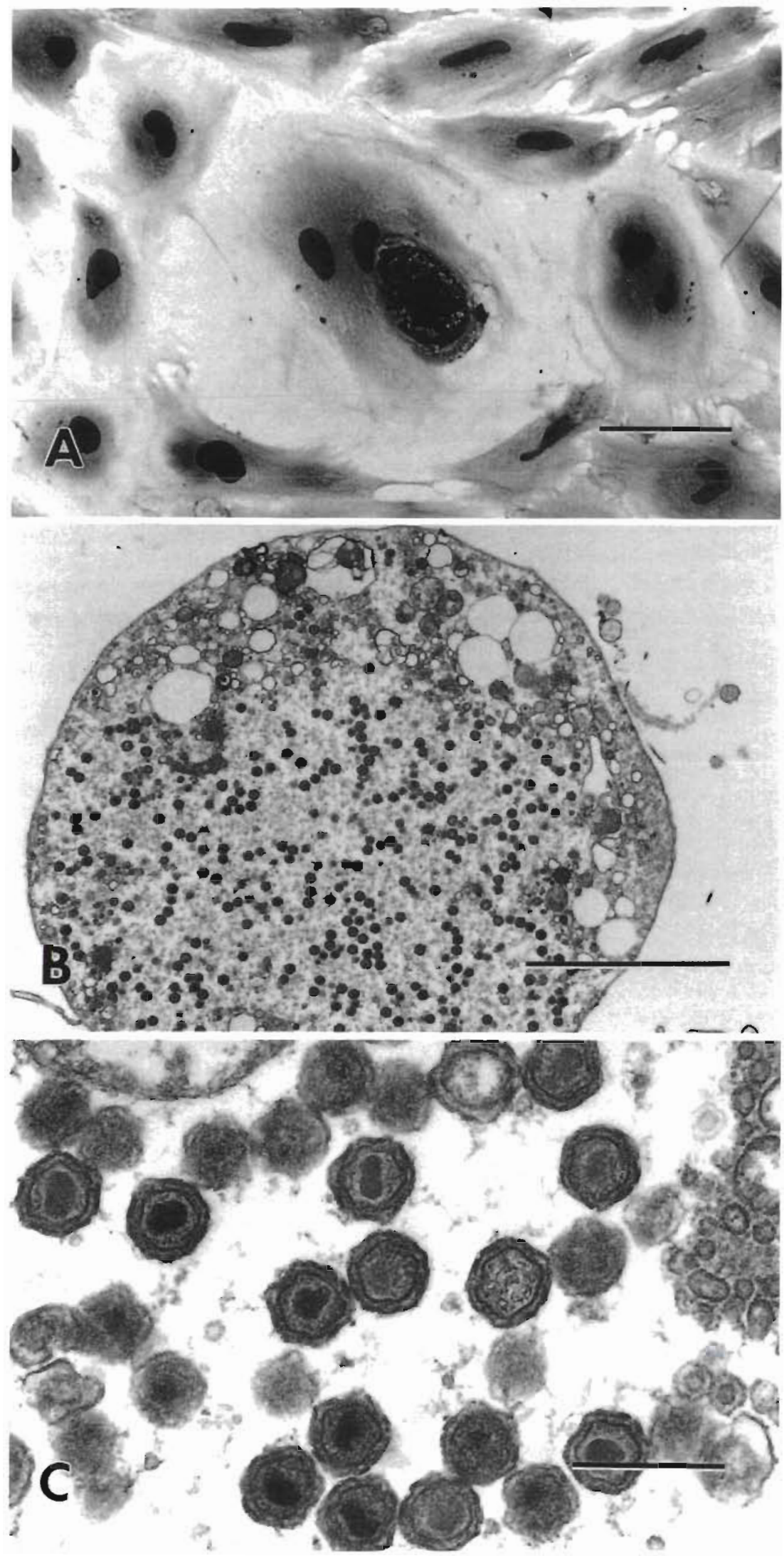

Fig. 1 Acipenser transmontanus. Spleen (WSS-2) cells infected with the white sturgeon iridovirus-like agent (WSIV). (A) Light micrograph $10 \mathrm{~d}$ following exposure to virus at $15^{\circ} \mathrm{C}$. A dark-stained dense granular appearing cell is detected on top of 2 fused cells; LeishmanGiemsa stain. Scale bar $=25 \mu \mathrm{m}$. (B) Electron micrographs of cells $21 \mathrm{~d}$ after incubation at $20^{\circ} \mathrm{C}$; large cytoplasmic vacuoles are found peripherally located throughout the cytoplasm and a fine matrix contains numerous hexagonal virus particles. Scale bar $=5 \mu \mathrm{m}$. (C) Virions with double shells; internal membrane surrounds an electron-dense bar. Scale bar $=500 \mathrm{~nm}$ 


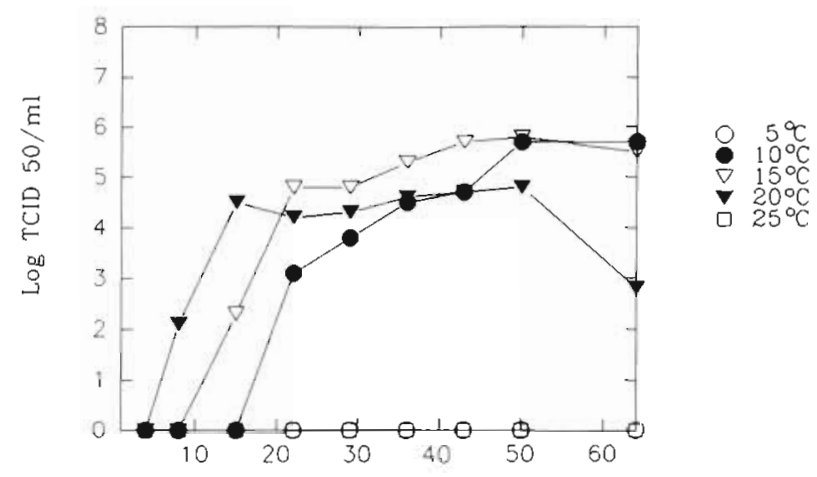

Fig. 2. Acipenser transmontanus. Growth of the white sturgeon irido-like virus (WSIV) in WSS-2 cells at 5 temperatures

\section{Determination of nucleic acid type, chloroform sensitivity and temperature stability}

There was no evidence of WSIV replication in the presence of $50 \mu \mathrm{g} \mathrm{ml}^{-1}$ of BUDR while untreated infections produced $10^{5.6} \mathrm{TCID}_{50} \mathrm{ml}^{-1}$ after 28 d at $20^{\circ} \mathrm{C}$ (Table 1). A similar reduction in CCV production using BUDR was observed in channel catfish ovary cells after $5 \mathrm{~d}$ at $25^{\circ} \mathrm{C}$. In contrast, IPNV replication in the CHSE214 cell line was unchanged by the addition of the inhibitor $\left(10^{9} \mathrm{TCID}_{50} \mathrm{ml}^{-1}\right.$ in treated and untreated cells) after $7 \mathrm{~d}$ incubation at $20^{\circ} \mathrm{C}$.

Chloroform treatments eliminated the infectivity of WSIV and CCV (Table 1). In contrast, IPNV infectivity was unaffected by the same treatment. Although WSIV was sensitive to $56^{\circ} \mathrm{C}$ for $30 \mathrm{~min}, 0.1 \%$ of the residual infectivity remained after treatment (Table 1 ).

\section{Transmission trial}

Cumulative mortality among juvenile white sturgeon exposed to WSIV was $80 \%$ after $50 \mathrm{~d}$ at water temperatures of $15^{\circ} \mathrm{C}$ (Fig. 3). Moribund fish displayed signs of anorexia beginning at $10 \mathrm{~d}$ post exposure and fell to the bottom of the tank prior to death. Virus was recovered from all but 2 fish that died during the study. Virus concentrations in selected dead fish ranged from $10^{4.5}$ to $10^{5.0} \mathrm{TCID}_{50} \mathrm{~g}^{-1}$. There were no mortalities among lake sturgeon, channel catfish or striped bass exposed to the virus nor among control groups of all 4 species. Virus was recovered from 4 of 4 virus-exposed live white sturgeon removed 1,2 and 4 wk postinfection but not from 2 and 1 fish examined at 6 and 9 wk, respectively. The virus was also recovered from 3 of 4 lake sturgeon examined at 1 wk postinfection and from 1 of 4 fish examined at 2 wk but not thereafter. Virus was not recovered from exposed channel catfish,
Table 1 Effects of 5-bromo-2'-deoxyuridine (BUDR) on viral replication, and the sensitivity to chloroform and temperature of the white sturgeon iridovirus-like agent (WSIV). Virus concentrations after various treatments in both control and experimental groups were determined by calculating the TCID $_{50}$ after incubations of $28 \mathrm{~d}$ on WSS- 2 cells at $20^{\circ} \mathrm{C}$ for WSIV; $5 \mathrm{~d}$ on CCO cells at $25^{\circ} \mathrm{C}$ for CCV; and $7 \mathrm{~d}$ on CHSE214 cells at $20^{\circ} \mathrm{C}$ for IPNV. nd: not done

\begin{tabular}{|c|c|c|c|}
\hline \multirow[b]{2}{*}{ Virus } & \multicolumn{3}{|c|}{ Virus concentration $\left(\mathrm{TCID}_{50} \mathrm{ml}^{-1}\right)$} \\
\hline & Control & BUI & $\mathrm{DR}\left(50 \mu \mathrm{g} \mathrm{ml}^{-1}\right)$ \\
\hline WSIV & $10^{5.2}$ & & $<10^{1.6}$ \\
\hline $\mathrm{CCV}$ & $10^{83}$ & & $10^{22}$ \\
\hline IPNV & $10^{9.3}$ & & $10^{92}$ \\
\hline Virus & Control & Chloroform & $56{ }^{\circ} \mathrm{C}(30 \mathrm{~min})$ \\
\hline WSIV & $10^{56}$ & $<10^{1.6}$ & $10^{2.7}$ \\
\hline $\mathrm{CCV}$ & $10^{8.1}$ & $<10^{1.6}$ & nd \\
\hline IPNV & $10^{9.9}$ & $10^{9.4}$ & nd \\
\hline
\end{tabular}

striped bass or control groups of any of the 4 species of fish examined at $1,2,4,6$ and $9 \mathrm{wk}$ after initiation of the study.

Hypertrophied, amphophilic to deeply basophilic cells in the integument and gill epithelium were prominent microscopic features among white sturgeon sampled 1 and 2 wk postinfection with WSIV. In addition, there was an associated gill epithelial hyperplasia with epithelial cell degeneration and necrosis and an infiltration of inflammatory cells as previously

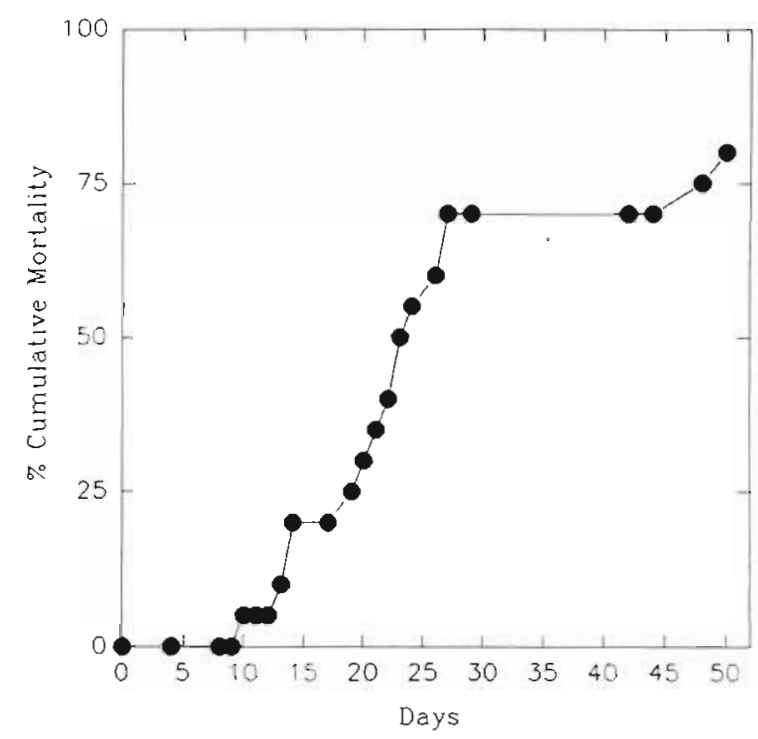

Fig. 3. Acipenser transmontanus. Cumulative mortality among juveniles following bath exposures to the white sturgeon iridovirus-like agent (WSIV) at water temperatures of $15^{\circ} \mathrm{C}$. Fish were exposed to $10^{2.9} \mathrm{TCID}_{50}$ of virus from WSS-2 cells $\mathrm{g}^{-1}$ fish. There was no mortality among a control group treated in the same manner but not exposed to the virus 
described for natural infections with WSIV (Hedrick et al. 1990). Lake sturgeon examined at 1 and $2 \mathrm{wk}$ displayed similar histopathologic changes in the gill epithelium but the hypertrophied cells were not prominent.

\section{DISCUSSION}

Initial investigations of yearly losses among juvenile white sturgeon reared in commercial farms in the state of California, USA, showed an association between the presence of an iridovirus-like agent and severe infections of the integument and gills (Hedrick et al. 1990). The virus was suspected to be the cause of the mortalities but the mability to isolate the agent precluded its confirmation as the etiological agent. The isolation of WSIV using cell lines derived from white sturgeon, followed by a demonstration of its virulence in infectivity trials, indicates the potential severity of the virus to farm-reared populations of white sturgeon.

Although the virus can be isolated using newly developed sturgeon cell lines, virus replication is slow and CPE is not easily observed before $14 \mathrm{~d}$ incubation and not routinely before $21 \mathrm{~d}$. The enlarged, rounded and deeply basophilic characteristics associated with these infected cells in vitro (Fig. 1A) correspond well with those observed in the integument and gills of both natural and experimentally-infected sturgeon. These pathognomonic cellular changes have been reported from previous outbreaks (Hedrick et al. 1990) and presumably correspond to accumulations of viral DNA in the cytoplasm of infected cells (Murti et al. 1985). Similar basophilic cytoplasmic inclusions have been described by Berry et al. (1983) for the goldfish iridoviruses (GFV 1 \& 2) during their replication in CAR cells derived from goldfish Carassius auratus.

Electron microscopy showed that infected WSS-2 cells contained numerous virions distributed throughout the cytoplasm (Fig. 1B). Infectivity assays indicated that up to $70 \%$ of the virus remains in the cells at $28 \mathrm{~d}$ post inoculation, a time at which cell detachment has occurred. With the exception that the virion diameter was slightly smaller ( $262 \mathrm{~nm}$ compared to $273 \mathrm{~nm}$ ), the size, shape and ultrastructure of the WSIV was identical in both WSS-2 cells (Fig. 1C) and infected cells of the diseased sturgeon (Hedrick et al. 1990). The osmiophilic core of the virions observed both in cell cultures and sturgeon tissues is presumed to be DNA based on its staining characteristics and the inability of the virus to replicate in the presence of the analog inhibitor BUDR. Although the resolution of the micrographs was insufficient to resolve inner and outer membranes associated with the 2 shells, the thickness of the WSIV shell layers (10 to $12 \mathrm{~nm}$ ) is larger than the corresponding components of the fish iridovirus causing lymphocystis disease $(2.5$ to $5.0 \mathrm{~nm}$ ) which does contain both the inner and outer membranes (Berthiaume et al. 1984). Sensitivity of WSIV to chloroform also supports the existence of an essential lipid-containing membrane or envelope.

Lymphocystis disease virus (LDV) shares some ultrastructural similarities to WSIV and infects cells in the integument. However, LDV selectively infects fibroblasts which continue to grow but cease to divide (Wolf 1962, Walker \& Hill 1980). The resulting hypertrophied cells are visible with the unaided eye (Wolf 1988). In contrast to WSIV infections, LDV is generally considered nonlethal and infected cells are periodically sloughed.

Replication of the WSIV was observed at 10,15 and $20^{\circ} \mathrm{C}$ with an optimum at $15^{\circ} \mathrm{C}$ (Fig. 2) which corresponds to water temperatures of 15 to $20^{\circ} \mathrm{C}$, commonly found in sturgeon farms where the disease is problematic (Hedrick et al. 1990). The inability of the virus to replicate at $25^{\circ} \mathrm{C}$ may allow for potential control of infections in vivo since white sturgeon grow well at this temperature (S. Hung pers. comm.). In contrast, the ability of the virus to survive temperatures of up to $56{ }^{\circ} \mathrm{C}$ for periods of $30 \mathrm{~min}$ suggests a stability that could contribute to the spread of the agent with commonly used equipment at the fish farm if disinfection procedures are not utilized. Pathogenicity of WSIV was demonstrated by the mortality of fish exposed via the water route. Fish dying in experimental exposures had the same emaciated appearance observed among white sturgeon in natural outbreaks. Mortality among white sturgeon was greatest during the period from 15 to $30 \mathrm{~d}$ post exposure (Fig. 3), and the virus recovered (up to $10^{5} \mathrm{TCID}_{50} \mathrm{~g}^{-1}$ ) from all but 2 fish examined. Although no mortality occurred, WSIV was also recovered from lake sturgeon indicating their susceptibility to infection but resistance to the more severe disease observed in white sturgeon. The lack of mortality or recovery of the virus from channel catfish and striped bass suggests that they are refractory to infection.

Although an iridovius-like agent has been isolated from carp Cyprinus carpio suffering from gill necrosis (Shchelkunov \& Shchelkunova 1981, 1984), recent studies indicate that the virus is not the causative agent of the gill disease (Shchelkunov \& Shchelkunova 1990). The other iridoviruses or iridovirus-like agents for which sufficient information exists seemingly cause distinctly different syndromes from WSIV, including severe systemic diseases (Jensen et al. 1979, Sorimachi \& Egusa 1982, Langdon \& Humphrey 1987, Wolf 1988, Ahne et al. 1989, Ogawa et al. 1990).

We presume that WSIV is a newly recognized and unique piscine iridovirus-like agent. The specificity of 
the virus for sturgeon Acipenser spp.) in vitro (cell lines) and in vivo suggest that the original source of the virus was the wild sturgeon held for brood stocks at most farms. This is supported in part by our observations of infections in some of the first artificially spawned progeny from these wild stocks in archival histological material beginning as early as 1983. Our experimental studies confirm the potential of this agent to induce serious losses as observed among cultured white sturgeon in California. Although California and recently Oregon (unpubl. own data) are the only confirmed geographic locations where WSIV has been detected, we suppose that the export of white sturgeon from California to other states and countries has created the potential for a considerably larger range for the agent.

Acknowledgements. This work was supported in part by Dingell-Johnson/Wallop-Breaux Fish Restoration Act funds administered through the California Department of Fish and Game (USA). Thanks to Mr Lynn Watson for assistance, and the technicians of the Veterinary Medicine Teaching Hospital for preparations of stained tissue sections for light microscopy, and Mr R. Munn for electron microscopy expertise. We also thank the Wisconsin Department of Natural Resources (USA) for providing the lake sturgeon.

\section{LITERATURE CITED}

Amos, K. (1985). Procedures for the detection of certain fish pathogens. Fish Health Section Bluebook, American Fisheries Society, Bethesda, Maryland

Ahne, W., Ogawa, M., Schlotfeldt, H. J. (1990). Fish viruses: transmission and pathogenicity of an icosahedral cytoplasmic deoxyribovirus isolated from sheatfish (Silurus glanis). J. vet. Med. 37: 187-190

Ahne, W., Schlotfeldt, H. J., Thomsen, I. (1989). Fish viruses: isolation of an icosahedral cytoplasmic deoxyribovirus from sheatfish (Silurus glanis). J. vet. Med. 36: 333-336

Berry, E. S., Shea, T B., Gabliks, J. (1983). Two iridoviruses from Carassius auratus (L.). J. Fish Dis. 6: 501-510

Berthiaume, L., Alain, R., Robin, J. (1984). Morphology and ultrastructure of lymphocystis disease virus, a fish iridovirus, grown in tissue culture. Virology 135: 10-19

Fijan, N, Sulimanovic, D., Bearzotti, M., Muzinine, D., Zwillenberg, L. D., Chilmonczyk, S., Vantheron, S. F., de Kinkelin, P. (1983). Some properties of the epithelioma papillosum cyprini (EPC) line from common carp Cyprinus carpio. Ann. Virol. 134: 207-220

Hedrick, R. P., McDowell, T. (1987). Passive transfer of sera with anti-virus neutralizing activity from adult channel catfish protects juveniles from channel catfish virus disease. Trans. Am. Fish. Soc. 116: 277-281

Hedrick, R. P., Groff, J. M., McDowell, T. S., Wingfield, W. H. (1991a). Isolation of an epitheliotropic herpesvirus from cultured white sturgeon (Acipenser transmontanus). Dis. aquat. Org. 11: 45-48

Hedrick, R. P., Mc Dowell, T. S., Rosemark, R., Aronstein, D.,
Lannan, C. N. (1991b). Two cell lines from white sturgeon. Trans. Am. Fish. Soc. 120: 528-534

Hedrick, R. P., Yun, S., Wingfield, W. H. (1991c). A small RNA virus from salmonid fishes in California, U.S.A. Can J. Fish. Aquat. Sci. 48: 99-104

Hedrick, R. P., Groff, J. M., McDowell, T. S., Wingfield, W. H. (1990). An iridovirus from the integument of white sturgeon. Dis. aquat. Org. 8: 39-44

Hedrick, R. P., Speas, J., Kent, M. L., McDowell, T (1985). Adeno-like virus associated with a disease of cultured white sturgeon (Acjpenser transmontanus). Can J. Fish. aquat. Sci. 42: 1321-1325

Humason, G. L. (1979). Animal tissue techniques. W. H. Freeman \& Co., San Francisco

Jensen, N. J., Bloch, B., Larsen, L. J. (1979). The ulcussyndrome in cod (Gadus morhua) A preliminary virological report. Nor. Vet. Med. 31: 436-442

Langdon, J. S., Humphrey, J. D. (1987). Epizootic haematopoietic necrosis, a new viral disease in redfin perch Perca fluviatilis L. in Australia. J. Fish Dis. 10: 298-297

Lannan, C. N., Winton, J. R., Fryer, J. L. (1984). Fish cell lines. establishment and characterization of nine cell lines from salmonids. In Vitro 20:671-676

Murti, K. G., Goorha, R., Granhoff, A. (1985). An unusual replication strategy of an animal iridovirus. Adv, viral Res. 30 $1-19$

Ogawa, M., Ahne, W., Fischer-Scherl, T., Hoffmann, R. W. Schlotfeldt, H. J. (1990). Pathomorphological alterations in sheatfish fry (Silurus glanis) experimentally-infected with an iridovirus-like agent. Dis. aquat. Org. 9: 187-191

Reed, L. J., Meunch, H. (1938). A simple method of fifty percent endpoints. Am. J. Hyg. 27: 493-497

Rovozzo, G. C., Burke, C. N. (1973). A manual of basic virological techniques. Prentice-Hall, Inc., Englewood Cliffs, New Jersey

Shchelkunov, I. S., Shchelkunova, T. I. (1981). Resultati viruslogichskich issoledovani bolnych nekrozom zhabr karpov. In: Olah, J., Molnar, K., Jeney, Z. (eds.) Proceedings of an international seminar on fish, pathogens and environment in European polyculture. (June 23-27, 1981). Fisheries Research Institute, Szarvas, Hungary, p. 466-482

Shchelkunov, I. S., Shchelkunova, T. I. (1984). Results of virological studies on gill necrosis. In. Olah, J. (ed.) Symposium Biologica Hungarica. Akademiai Kiado, Budapest, Hungary 23: 31-43

Shchelkunov, I. S., Shchelkunova, T. I. (1990). Infectivity experiments with Cyprinus carpio iridovirus (CCIV), a virus unassociated with carp gill necrosis. J. Fish Dis. 13: $475-484$

Sorimachi, M., Egusa, S. (1982). Characteristics and distribution of viruses isolated from pond-cultured eels. Bull. natn Res. Inst. Aquacult. 3: 97-105

Walker, D. P., Hill, B. J. (1980). Studies on the culture, assay of infectivity, and some in vitro properties of lymphocystis virus. J. gen. Virol. 51: 385-395

Wolf, K. (1962). Experimental propagation of lymphocystis disease of fishes. Virology 18: 249-256

Wolf, K. (1988). Fish viruses and viral diseases. Cornell University Press, Ithaca, New York

Yasutake, W. T., Wales, J. H. (1983). Microscopic anatomy of salmonids: an atlas. United States Department of the Interior, Fish and Wildlife Service, Resource Publication 150, Washington, D.C. 